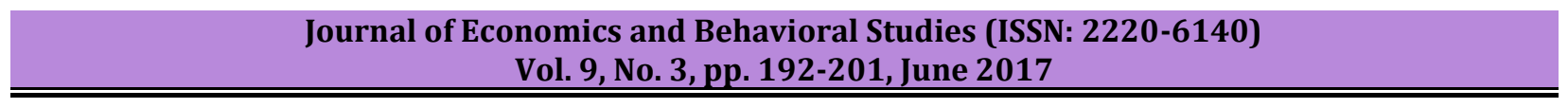

\title{
The Role of E-Banking on the Switching Behaviour of Retail Clients of Commercial Banks in Polokwane, South Africa
}

\author{
Reginald Masocha, Tafadzwa Matiza \\ School of Economics and Management, University of Limpopo, South Africa \\ reginald.masocha@ul.ac.za,matizata@hotmail.com
}

\begin{abstract}
This study focused on investigating the role of E-banking on the switching behaviour of retail bank clients in Polokwane, South Africa. Recently, studies have shown that people are switching banks more often than in the past. Circumstances that are beyond control cause people to switch. This has become a challenge in the banking industry as many banks lose their clients. However, newly developed technologies have brought many changes in the operation of banks. The new E-banking services have enabled bank clients to have access to their bank account for 24 hours without visiting the physical branch. A sample of 98 respondents was surveyed in Polokwane, South Africa using the convenience sampling technique. The cronbach alpha test was used to ascertain reliability of the findings. The findings reveal that demographic characteristics have much impact on the switching behaviour of commercial bank clients and acceptance of ebanking services. Switching factors such as bank charges, low interest rates on savings, promotion activities, location and switching costs were the major reasons for bank customers to switch banks.
\end{abstract}

Keywords: E-banking, Customer Switching behaviour, Switching Barriers, South Africa's banking industry

\section{Introduction}

Within the contemporary business environment, the propensity of financial service consumers switching service providers has significantly increased - buoyed by the competitive pressures arising from the deregulation of the banking sector by individual economies from the early 1980's to present day, economic integration associated with globalisation and more pertinently, advances in information and communication technology - ICT (Clemes, Gan \& Zheng, 2007; Kura, Mat, Gorondutse, Magaji \& Yusuf, 2012; Wu, 2005). The proliferation of electronic banking (E-banking) in the South African banking services sector has, since its introduction in 1996, become a major component of banking services and product delivery - debunking the traditional bank-branch oriented services (Addae-Koranye, 2014; Chavan, 2013; Wu, 2005). The utilisation of internet-based services and products within the South African banking sector is extensive and has been found to have a critical impact on the consumer behaviour of bank clients (Gouws, 2012; Redelinghuis \& Rensleigh, 2010; $\mathrm{Wu}, 2005)$. This shift in consumer behaviour includes the subject matter of this paper, customer switching behaviour.

Customer switching is the undesirable effect of an increasingly innovative and competitive market in any service oriented industry, more-so in the South African financial services sector. The literature (Khan, Ghouri, Siddaqui, Shaikh \& Alam, 2010; Pirzada, Nawaz, Javed \& Asab, 2014) intrinsically links customer retention with the profitability of banking institutions. Khan et al. (2010) and Gouws (2012) consider customer switching to have a discernible antipodal relationship with the operating costs of organisations, as increased customer switching ultimately results in increased marketing and customer retention costs. To this end, Onditi (2013) argues that there is a golden thread between service features and customer loyalty, in relation to customer retention and organisational performance, respectively. The South African banking sector is highly competitive and is characterised as saturated by Chigamba and Fatoki (2011), who go on to ascertain that consumers are privy to unlimited switching options. The extent of technological innovation in the South African banking sector through e-banking and the subsequent impact on customer switching behaviour is a relatively novel discourse. This is so especially within a predominantly rural region such as Limpopo Province, South Africa. This study therefore, contributes to an improved understanding of e-banking as an antecedent of switching behaviour within the surveyed population. It is with this in mind that this study was conducted, particularly to establish the impact of e-banking on the switching behaviour of retail banking clients of commercial banks within the Polokwane City locale, which is the provincial capital of Limpopo Province, South Africa. 
Aim, Objectives and Hypotheses: The aim of this research was to interrogate the role played by E-banking on the switching behaviour of commercial bank clients in the Polokwane City. The following were the objectives of the study:

- To examine the contribution of e-banking in customers' bank switching behaviour in Polokwane banking sector.

- To determine the extent to which bank customers are being affected by switching factors in Polokwane.

- To determine the extent to which e-banking provides switching costs.

- To determine the impact of the demographic characteristics on the customers' switching behaviour on e-banking.

In order to realise the aforementioned objectives, the following research hypotheses were tested:

\section{Primary hypothesis}

$\mathrm{H}_{0}$ : E-banking does not play a significant role on customers' bank switching behaviour.

$\mathrm{H}_{1}$ : E-banking does play a significant role on customers' bank switching behaviour.

\section{Secondary hypotheses}

$\mathrm{H}_{0}$ : The extent to which bank customers are being affected in by switching factors cannot be determined.

$\mathrm{H}_{2}$ : The extent to which bank customers are being affected by switching factors can be determined.

$\mathrm{H}_{0}$ : Switching costs on e-banking services are the barriers that retain customers from switching banks.

$\mathrm{H}_{3}$ : Switching costs on e-banking services are not a barrier in retaining customers from switching bank as ebanking providing low switching costs.

$\mathrm{H}_{0}$ : Demographic characteristics have no impact in the customers' bank switching behaviour and acceptance of e-banking.

$\mathrm{H}_{4:}$ Demographic characteristics have much impact in the customers' bank switching behaviour and acceptance e-banking.

\section{Literature Review}

Overview of E-banking in South Africa: The internet have revolutionised the contemporary global financial services market. In the case of the banking industry, the internet and its associated new technologies have resulted in the introduction of new web-based financial services products. This has increased innovationbased competition between financial services providers as consumers become more circumspect in their banking service choice (Clemes et al., 2007). E-banking is essentially the provision of financial services and products via electronic platforms (Addae-Koranye, 2014; Chavan, 2013; Chibueze, Maxwell \& Osondu, 2013; $\mathrm{Wu}, 2005$ ) - and these include automated teller machines (ATMs), internet banking and cell-phone banking. The benefits of which include: reduced transaction costs associated with banking; customer convenience; better financial management and; improved access to information for both clients and bankers (ibid). In the case of South Africa, one major banking group provides the following e-banking services:

Table 1: E-banking services provided by a major South African bank

\begin{tabular}{lccc}
\hline Features & $\begin{array}{c}\text { Telephone } \\
\text { banking }\end{array}$ & ATM & $\begin{array}{c}\text { Internet } \\
\text { banking }\end{array}$ \\
\hline Withdrawals & & \\
Deposits & & \\
Balance enquiries & & \\
Interim statements & & \\
Transfer of funds & & \\
Cheque payments & & \\
Stop orders & & \\
Rates & & \\
\hline
\end{tabular}

Source: Wu (2005) 
It is important to note that before the advent of e-banking, the services outlined above required physical interaction between the bank and its clients. Therefore, probably the more important attribute of e-banking is that it made banking more convenient, more accessible and more importantly, significantly reduced the cost of doing business for banks and transaction costs for the consumer. This view is similarly expressed by Wu (2005). E-banking has to a larger extent been considered as a revolutionary force in South Africa's banking sector, expediting customer service and ensuring the efficiency for the financial services sector (Redelinghuis \& Rensleigh, 2010). A South African banking industry survey by Price water house Coppers - PwC (2013) found that along with traditional retail and personal banking, e-banking is still a very important and competitive retail banking segment - with many banks realising significant revenue growth and profitability from e-banking products and transactions. Additionally, technology is considered to be a key catalyst in the innovation of the South Africa's banking sector, with the four largest banks in South Africa investing an estimated R3-R5 billion into electronic channels (PwC, 2013).

Customer switching behaviour: Khan et al. (2010) pointedly refer to customer switching as customer defection or exit. While, Pirzada et al. (2014) simply define switching behaviour by viewing the concept from two perspectives - switching which refers to making a shift, change or exchange, and behaviour which refers to taking proactive or reactive action to something. Gouws (2012) views customer switching behaviour as a form of customer attrition, which impinges on the competitiveness and profitability of South African retail banks in particular. From this simplified viewpoint, for the purposes of this paper bank customer switching behaviour may be characterised as the propensity of bank customers to change their banking service provider in reaction to or in anticipation of certain factors. The prevention of customer switching (customer retention) has increasingly become a significant competitive strategy within the banking industry as it costs significantly less to retain a customer than it is to recruit new customers (Clemes et al., 2007; Subramaniam \& Ramachandran, 2012).

Empirical evidence on customer switching behaviour in the banking sector: According to Manrai and Manrai (2007), customer switching behaviour may be explained across four broad categories, personnel, environmental, convenience and/or financial. Relatedly, a review of literature on service switching by Clemes et al. (2007) found more in-depth evidence that certain industry specific factors contributed to customer switching behaviour: dissatisfaction; poor service and perception of quality were significant influencers in customer switching in the insurance, retail and banking sectors respectively. With specific reference to the banking sector the following salient factors are identified:

Table 2: Salient factors influencing customer switching in the banking sector

\begin{tabular}{ll}
\hline Authors & Factors influencing bank customer switching behaviour \\
\hline Colgate and Hedge & $\begin{array}{l}\text { Pricing issues (fee, charges, interest rate), service failures (mistake, inflexible, } \\
\text { inaccessible, unprofessional), and denied services (denied loan, no advice) }\end{array}$ \\
$\begin{array}{l}\text { Gerrard } \\
\text { Cunningham and }\end{array}$ & $\begin{array}{l}\text { Inconvenience, service failures, pricing, unacceptable behaviour, attitude or } \\
\text { knowledge of staff, involuntary/seldom mentioned incidents, and attraction by } \\
\text { (2000) }\end{array}$ \\
competitors \\
Peaveney (1995) & $\begin{array}{l}\text { Pricing, inconvenience, core service failure, service encounter failure, response to } \\
\text { service failure, ethics, competition, and involuntary switching }\end{array}$ \\
Stewart (1998) & Facilities, provision of information and confidentiality, and services issues \\
\hline
\end{tabular}
Adapted from: Clemes et al. (2007)

As illustrated in Table 2 there are some common salient factors that may be considered to be generic in influencing banking customers to switch banks and these include: pricing of banking products and services (including switching costs); service quality (including turnaround time in services and products); banking facilities (convenient access to products and services) and; competition from other financial services providers (intensity of advertising, pricing and innovativeness). In their analysis of the determinants of customer switching amongst bank clients in Pakistan, Khan et al. (2010:105) from a convenient sample of $n=302$ customers from 20 major private banks found that there was a positive relationship between customer switching and an unfavourable perception of pricing, unfavourable bank reputation, unfavourable service quality, unfavourable perception of distance and, effective advertising competition. A negative relationship was found between switching costs and customer switching. Relatedly, Pirzada et al. (2014) in 
their empirical study on the factors influencing the switching behaviour of Pakistani banking consumers found, based on data from a convenient sample of $n=200$ banking clients, a statistically positive relationship between customer switching behaviour and the following independent variables: bank branches (convenience of location \& access); service quality and; profit and interest rates. In a study on customer switching behaviour in New Zealand's banking industry, Clemes et al. (2007) applied a Qualitative Choice Model of customer switching behaviour on a final sample of $n=454$ households - found that customer commitment had the strongest impact on the switching intention of banking consumers in New Zealand, followed by service quality, reputation and customer satisfaction respectively.

The impact of E-banking on customer behaviour: The literature reviewed (Chavan, 2013; Masocha, Chiliya \& Zindiye, 2011), suggests that e-banking improves the overall customer satisfaction of banking clients over a wider geographical area including previously disadvantaged rural communities. Gouws (2012) identifies: regulatory changes (introduction of Basel III); technology shifts (increased investment in ICT platforms and processes); innovation (cost reduction driven e-banking channel modernisation) and; changing market dynamics (increasingly competitive retail banking sector) as the factors influencing the contemporary South African retail banking sector. With particular reference technology and innovation, in the South African context e-banking, according to a PwC (2013) survey, offers customers significant benefits which include: added convenience; transaction cost reduction; seamlessness, increased functionality and confidentiality, as well as; simplicity in banking. These benefits may be expected to positively impact on consumers and mitigate switching intention. Similarly, in the case of Nigeria, Chibueze, Maxwell and Osondu (2013) found that ebanking has expanded the country's banking sector, opening new distribution channels for banking services and products. To the best of our knowledge no empirical study has been conducted to examine the impact of e-banking on customer switching behaviour in the South African context.

\section{Methodology}

A quantitative study was conducted with the aim of generating computable data that would empirically address the aim of the study (Blumberg, Cooper \& Schindler, 2008). However, the study employed the nonprobability sampling approach to establish its study population. Non-probability sampling is increasingly being adopted by marketing oriented studies that are quantitative in nature (Mathers, Fox \& Hunn, 2007). Although convenience sampling did not afford all bank account holders in the province an opportunity to participate in the study, the sampling technique is widely recommended for studies whose total population cannot be determined at the start of the study (Cooper \& Greenaway, 2015:3). Convenience sampling, which focuses on accessing the easiest to reach population elements for the purposes of the study, was employed to solicit participation in the study (Mugera, 2013). As a result, 98 respondents were interviewed through the use of survey questionnaires at two popular shopping malls, namely Mall of the North and Savanna Mall located in the Polokwane Province of South Africa. The data generation instrument (questionnaire) used in this study was structured in three sections.

- Section A captured basic banking information and the usage of e-banking services;

- Section B captured information about the customers' bank switching behaviour and;

- Section C captured information about demographics.

Multiple choice, Likert scale, dichotomous, open and closed ended questions were used. A chi-square test of association was used with 95\% confidence level. The Cronbach alpha test was used to test for the reliability of the research questions. In order to conclude on the reliability of the research questions, the Cronbach alpha had to be the value greater than 0.53 .

\section{Results}

This section of the paper presents the findings of the study.

Demographic profile: The data on gender reveals that out of the total number of respondents, $51 \%$ were males and $49 \%$ were females. The majority of the respondents were younger than 30 years. The modal marital status was for single people with $71 \%$ of respondents whereas $20 \%$ were married, $5 \%$ divorced and $3 \%$ were widowed. The researchers strived to distribute the questionnaires in all racial groups as South 
Africa's population is very diverse; however, the area where the data was collected is much dominated by Black Africans. Thus, $76 \%$ were Blacks, $10 \%$ Coloureds, $8 \%$ Whites and $6 \%$ Indians. The research established that $74 \%$ of the respondents were in possession of a tertiary education, while $9 \%$ and $17 \%$ had only acquired the primary or high school education, respectively. The majority of respondents were earning less than R10 000 per month. The income modal group was 0-R5 000.

Banking Profile of respondents: The findings on respondents' duration of banking, 1 year and 35 years represent the minimum and maximum period, respectively. Most respondents had been with their banks for 4 years. The average of banking patronage by the respondent was 8.55 years. Respondents were asked to select their bank of first choice and they were also asked to indicate whether or not they had accounts with other banks. The findings showed that Standard bank is the most utilised bank with $41 \%$ of respondents and followed by FNB 24\%. The remaining 35\% has been shared amongst by Absa, Capitec, Nedbank and Post bank with $12 \%, 13 \%, 8 \%$ and $2 \%$, respectively. However, there were no respondents who banked with Investec bank. The majority of the respondents are holding accounts only with the bank of their first choice.

Usage of E-Banking Services: Figure 1 below reflects the findings when respondents were asked about the importance of e-banking in conducting their personal banking.

Figure 1: Importance of E-Banking Services

\section{Importance of E-banking services}

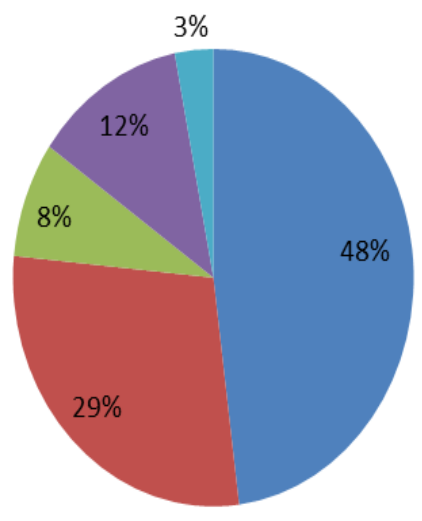

- very important

Important

Neutral

- Unimportant

Extremely unimportant

The study indicates that $77 \%$ of the respondents highlighted that e-banking was important in conducting their personal banking, $48 \%$ of them specifically considered it as very important. Only $15 \%$ of the respondents who highlighted that e-banking is unimportant, of which $3 \%$ of them considered it as extremely unimportant and $8 \%$ were neutral.

Table 3: E-banking Benefits

\begin{tabular}{|c|c|c|c|c|c|}
\hline & \multicolumn{5}{|c|}{ Valid percentages $\%$} \\
\hline & $\begin{array}{l}\text { Strongly } \\
\text { Agree }\end{array}$ & Agree & Neutral & Disagree & $\begin{array}{l}\text { Strongly } \\
\text { Disagree }\end{array}$ \\
\hline Reduces switching costs & 13.3 & 28.6 & 41.8 & 15.3 & 1.0 \\
\hline Improves bank service quality & 39.8 & 34.7 & 16.3 & 7.1 & 2.0 \\
\hline Increase bank information & 26.5 & 38.8 & 21.4 & 10.2 & 3.1 \\
\hline Removes switching barriers & 6.1 & 28.6 & 57.1 & 8.2 & 0 \\
\hline Provide cost effectiveness & 22.4 & 40.8 & 22.4 & 13.3 & 1.0 \\
\hline Are secure and trustworthy & 18.4 & 33.7 & 25.5 & 15.3 & 7.1 \\
\hline Minimize switching time & 9.2 & 26.5 & 55.1 & 6.1 & 3.1 \\
\hline Ease account accessibility & 40.8 & 16.3 & 32.7 & 9.2 & 1.0 \\
\hline
\end{tabular}




\begin{tabular}{llllll}
\hline Effective communication & 32.7 & 29.6 & 26.5 & 8.2 & 3.1 \\
Better self-management of finance & 30.6 & 36.7 & 23.5 & 8.2 & 1.0 \\
Easy and simple to use & 48.0 & 38.8 & 10.2 & 3.1 & 0 \\
Life-style compatibility & 29.6 & 40.8 & 25.5 & 3.1 & 1.0 \\
Ease use of ATMs of any bank & 52 & 32.7 & 12.2 & 2.0 & 1.0 \\
quick response to complaints & 12.2 & 21.4 & 54.1 & 10.2 & 2.0 \\
\hline
\end{tabular}

Impact of E-banking on Customers Switching Behaviour: The majority of the respondents agreed with the assertions that e-banking services reduced the cost of switching, improves bank service quality, increase information about the bank, are cost effective to them, are secure and trustworthy, allows bank clients to have an access in their account at any location with internet connection, makes them more comfortable to communicate with the bank, allows them to manage their finance, easy and simple to use, makes their lifestyle more convenient and enables them to use ATMs of any bank. However, the majority of respondents were not certain that e-banking removes the barriers for them to switch their banks and save time when switching to a new bank. The response of those who disagree with these perceptions was very low. This implies that e-banking services have the significant impact in the switching behaviour of retail clients of commercial banks. The diagram below (Table 3) indicates to what extent respondents agreed that e-banking services offered various benefits as outlined in the diagram.

Table 4: Chi-square test results-Objective 1

\begin{tabular}{lll}
\hline & $\mathbf{X}^{2}$-value & p-value \\
\hline Removes the barriers for me to switch from one bank to another & 66.0816 & 0 \\
Save time when switching to a new bank & 91.6939 & 0 \\
Enables me to use ATMs of any bank & 94.5510 & 0 \\
\hline
\end{tabular}

The first null hypothesis stated that: E-banking does not play a significant role on customers' bank switching behavior. From the results shown above, each statement on what e-banking does for retail commercial bank clients has a p-value $<0.05$ meaning $\mathrm{H}_{0}$ is rejected and it can be concluded that e-banking does play a significant role on customers' bank switching behavior.

Switching Behaviour: Also respondents were quizzed if they switched their principal banks in the last 3 years and the following was found (see Fig. 2).

Figure 2: Bank Switching

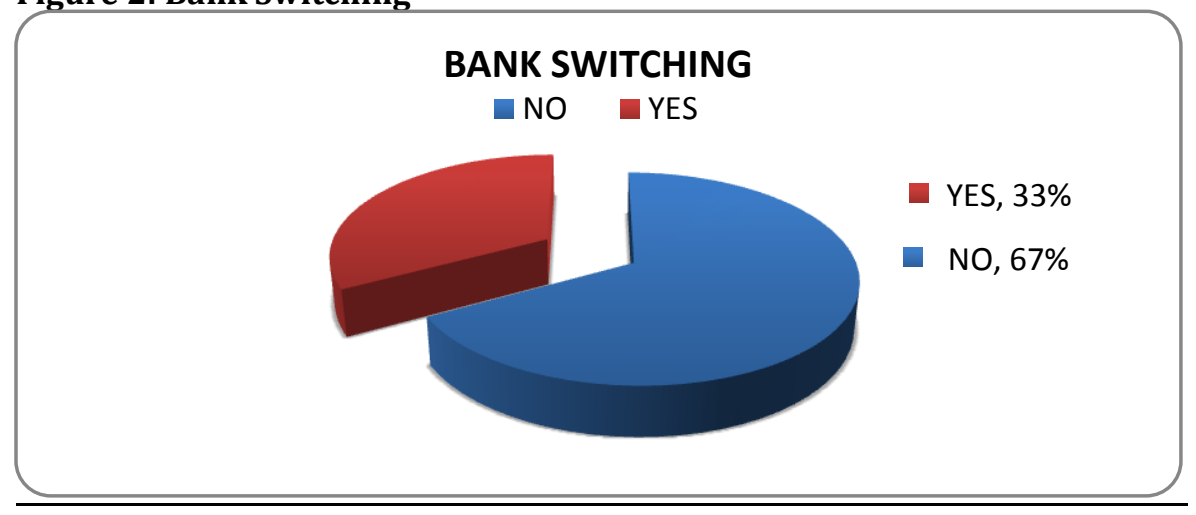

The findings show that 33\% of the respondents had switched their principal banks while $67 \%$ have not switched banks. The findings showed that males have switch banks than females. The findings also show that $67 \%$ of the respondents were non-switchers. However, 33\% of respondents were switchers and were answering questions on why they have switched. However, in the $33 \%$ of the respondents who had switched banks, $20 \%$ were uncertain, $9 \%$ disagree, $2 \%$ agree, and $2 \%$ strongly disagree that their bank's online system was unreliable. However, the $67 \%$ of respondents who have not switched banks, $35 \%$ were uncertain, $11 \%$ 
disagree, $6 \%$ strongly disagree, $10 \%$ agree and $5 \%$ strongly agree that their bank's online system was reliable.

Impact of bank charges and interest rates on customer switching: The responses of those who have not switched their banks showed that the majority of them have not switched banks because of low bank charges. However, the majority of respondents were not sure about the interest rates on savings account. The results indicated that $46 \%$ agreed, $8 \%$ were uncertain, $11 \%$ disagreed that their banks charged low fees while $4 \%$ strongly agreed, $21 \%$ agreed, $30 \%$ were uncertain, $10 \%$ disagreed and $2 \%$ strongly disagreed that their banks provided high interest rates on savings account. The results indicated that $20 \%$ agree that promotion activities from other banks had not influenced them to switch banks, of which $16 \%$ of them strongly agree. However, $15 \%$ were uncertain, $15 \%$ disagree and only $1 \%$ strongly disagree that they have not been influenced by the promotion activities from other banks.

The extent of switching and availability of bank branches: The majority of respondents agreed that availability of bank branches in their area is one of the factors that make them not to consider switching as a best option. In the case of relocation, those who have not switched disagree that it has an impact in changing banks. This means that though they have relocated but their banks are available in their immediate area.

Uncertainty about Benefits when switching to a new bank: The majority of respondents agreed that they had not switched to new banks because they were not sure that there are benefits they can receive. The results indicate that $9 \%$ strongly agreed, $17 \%$ agreed, $22 \%$ uncertain while $18 \%$ disagreed and $1 \%$ strongly disagreed that they were not sure about the benefits they will receive when switching.

Perception of switchers about switching costs: The majority of respondents were uncertain and some agree that they had switched banks because it would not cost them too much when switching to a new bank. The results indicated that $5 \%$ strongly agree, $10 \%$ agree, $15 \%$ were uncertain and $3 \%$ disagree.

Perception of non-switchers about switching costs: The secondary objective aimed at investigating about the extent to which e-banking services such as internet banking, Cellphone banking, ATM's, provide switching costs. The researcher was interested in investigated on whether e-banking services reduce or increase the costs of switching. The majority of the respondents were uncertain and some agree that they had not switched because of high switching costs to a new bank e-banking platform. The results indicated that $8 \%$ strongly agree, $12 \%$ agree, $29 \%$ were uncertain, $14 \%$ disagree and $4 \%$ strongly disagree.

\section{Table 5: Chi-square test of results-Objective 1}

\begin{tabular}{lll}
\hline & $\mathbf{X}^{2}$-value & p-value \\
\hline The bank's online system was unreliable & 147.2041 & 0 \\
The bank did not offer a wide range of service products & 184.0000 & 0 \\
The service products offered did not satisfy my specific needs & 187.0612 & 0 \\
The bank's online system is reliable & 52.7347 & 0 \\
The bank provides a wide range of service products & 51.8980 & 0 \\
The service products satisfy my specific needs & 41.4898 & 0 \\
\hline
\end{tabular}

The null hypothesis formulated in line with objective 1 states that: e-banking does not play a significant role on customers' bank switching behavior. From the results shown above, each statement on what banks provide through e-banking services for retail commercial bank clients has a p-value $<0.05$ meaning $\mathrm{H}_{0}$ is rejected and it can be concluded that e-banking does play a significant role on customers' bank switching behavior.

Table 6: Chi-square test of results-Objective 2

\begin{tabular}{lll}
\hline & $\mathbf{X}^{2}$-value & p-value \\
\hline The bank charged high fees & 202.9796 & 0 \\
The bank provided low interest rates on savings accounts & 188.7755 & 0 \\
$\begin{array}{l}\text { The promotion activity of the competing bank influenced my } \\
\text { decision to switch banks }\end{array}$ & 188.4082 & 0 \\
\hline
\end{tabular}




\begin{tabular}{|c|c|c|}
\hline The principal bank branches in my area are closed & 187.6735 & 0 \\
\hline $\begin{array}{l}\text { I moved to a new geographic location and my principal bank } \\
\text { is not in the area }\end{array}$ & 186.0816 & 0 \\
\hline $\begin{array}{l}\text { I am sure that I can receive additional benefits if I switch to a } \\
\text { new bank }\end{array}$ & 188.0408 & 0 \\
\hline The bank charges low fees & 36.8163 & 0.000001 \\
\hline The bank provides high interest rates on savings accounts & 50.5306 & 0 \\
\hline $\begin{array}{l}\text { The promotion activity of the competing bank do not } \\
\text { influenced my decision to switch banks }\end{array}$ & 30.0816 & 0.000014 \\
\hline There are bank branches in my immediate area & 52.2449 & 0 \\
\hline I have not moved to a new geographic location & 29.1020 & 0.000022 \\
\hline
\end{tabular}

The null hypothesis stated that: the extent to which bank customers are being affected by switching factors cannot be determined. From the results shown above, those who have switched together with those who have not switched their banks has a p-value $<0.05$ meaning $\mathrm{H}_{0}$ is rejected and it can be concluded that the extent to which customers are being affected by switching factors can be determined.

Table 7: Chi-square test of results-Objective 3

\begin{tabular}{lll}
\hline & $\mathbf{X}^{2}$-value & p-value \\
\hline It will not cost me too much to switch to a new bank & 141.0816 & 0 \\
It will cost me too much to switch to a new bank & 38.4082 & 0 \\
\hline
\end{tabular}

The null hypothesis state that: switching costs are the barriers that retain customers from switching banks. From the results shown above, statement of switching costs has a p-value $<0.05$ meaning $\mathrm{H}_{0}$ is rejected and it can be concluded that switching costs are no longer an effective strategy in retaining customers from switching bank as e-banking provides low switching costs.

Table 8: Chi-square test of association results-Objective 4

\begin{tabular}{lll}
\hline & $\mathbf{X}^{2}$-value & p-value \\
\hline Switching banks and gender & 2.506 & 0.113 \\
Switching banks and age group & 13.697 & 0.008 \\
Switching banks and marital status & 6.656 & 0.155 \\
Switching banks and race & 8.404 & 0.038 \\
Switching banks and level of education & 2.539 & 0.468 \\
Switching banks and income group & 7.905 & 0.048 \\
\hline
\end{tabular}

The null hypothesis states that: demographic characteristics have no impact in the customers' bank switching behavior and acceptance of e-banking. From the results shown above, gender, marital status and educational level in relation to banks switching have a p-value> 0.05 meaning they are insignificant. Thus, $\mathrm{H}_{0}$ is not rejected and it can be concluded that demographic characteristic have no impact in the customers' bank switching behavior. However, income group, race, and age group have p-values $<0.05$ meaning that in this case $\mathrm{H}_{0}$ is rejected and it can be concluded that demographic characteristic have much impact in the customers' bank switching behavior and acceptance of e-banking.

\section{Discussion \& Conclusion}

Based on the analysed data, gender inequality among males and female with bank account exist although this gap promises to disappear as more women get educated and employed in high position. The tradition that females are expected to stay at home caring for the children whilst men go to work seems to falling apart. Young age groups dominate the banking industry and seemingly are more equipped on the usage of ebanking services. This primarily owes to the fact that many young people are educated and education has shown to be a contributing factor in the acceptance and adoption of e-banking. Thus, more educated people are; the more likely they utilise e-banking. Also income and the level of education have a positive correlation, meaning that people with higher education are likely to earn higher incomes. This contributes towards high 
e-banking adoption levels. The data analysed highlights that the majority of respondents were those who have not changed their banks. However, this does not mean that these customers are still satisfied with their banks. Some continue to be loyal even though they are unsatisfied with their banks. This might be caused by the fact that they have been using these banks for a long time and are afraid to change after so long. The findings on the importance of e-banking are consistent with the research results of Masocha et al. (2011). This study found that the majority of people considered e-banking services as an important way of conducting their personal banking. The study also indicates that, responses on the banking methods such as internet banking and telephone banking showed that in a normal week the majority of respondents do not use these e-banking methods, respectively.

The demographics of this research are also consistent with some of the research results of Zhang (2009) conducted in New Zealand banks. In his study, he found that switching behaviour was most common with younger-aged and high educated bank customers. However, the results differ from some of the findings of Zhang (2009) who determined that higher income earners were the most likely to switch banks than low income earners. The findings about the impact of high price (e.g., bank charges, interest charges on loan) and low interest rates on savings accounts on customer switching behaviour are consistent with the research results of Keaveney, (1995); Colgate and Hedge, (2001); Dawes, (2004). However, the results on interest charges on loan differ from the findings of these authors because the majority of those who switched banks in the research findings were uncertain on whether they have switched because of high interest on loans. There are several suggestions that can be made specifically to the South Africa's banking industry concerning the problem of switching behaviour on e-banking podiums. First and foremost, the fees that banks charge from their customers have shown to be the biggest challenge that banks need to take into consideration. The empirical analysis revealed that the majority of those who switched banks strongly agree that high bank charges is one of the factors that cause them to switch. Secondly, another area of importance noted by respondents is that banks must improve their service quality in order to meet customer demands. Thirdly, innovation through the introduction of new e-banking services such as Cellphone banking, internet banking and electronic transfer at point of sale and withdrawals has shown a strong positive impact in the customer's satisfaction level with banks. Therefore, banks must ensure that they cut costs of providing these services.

Lastly, besides the areas that are highlighted in these recommendations, a lot can be learnt from the results obtained in the research. It is true that e-banking services have an impact in the banking industry. Thus, it is crucial for banks to consider factors that are prominent drawbacks in the usage of e-banking services such as client's lack of knowledge, insecurity and threats of technologies. It is evident that the majority of bank customers are still much relying on brick and mortar banks and this might be as a result of security in using ebanking methods and lack of knowledge on how to utilize e-banking services. Thus, banks need to consider the clients awareness and education on the new banking technologies. The sample used in this study was drawn from the Polokwane city population in South Africa. The demographic characteristics are a reasonable representation of the South Africa's population, the sample did contain a higher percentage of young people and a lower percentage of old people. Future studies should consider the demographic implications of their specific age group when they develop and examine the role played by e-banking in the switching behavior of retail clients of commercial banks. Researchers could then compare their results with the results of this study. In this study quota sampling was used and this sampling technique has many limitations that affect the representation of the findings. In quota sampling there is no randomness and the likelihood of bias is high. This has negative repercussion of failure to perfectly generalise the findings of the research to the whole population.

\section{References}

Addae-Korankye, A. (2014). The impact of e-banking on customer service and profitability of banks in Ghana. Global Journal of Commerce \& Management Perspective, 3(1), 61-65.

Blumberg, B., Cooper, D. R. \& Schindler, P. S. (2008). Business research methods. London: McGraw-Hill Higher Education.

Chavan, J. (2013). Internet banking benefits and challenges in an emerging economy. International Journal of Research in Business Management, 1(1), 19-26.

Chibueze, A. Z., Maxwell, O. O. \& Osondu, N. M. (2013). Electronic banking and bank performance in Nigeria. West African Journal of Industrial \& Academic Research, 6(1), 171-187. 
Chigamba, C. \& Fatoki, O. (2011). Factors influencing the choice of commercial banks by university students in South Africa. International Journal of Business and Management, 6(6), 66-76.

Clemes, M. D., Gan, C. \& Zheng, L. Y. (2007). Customer switching behaviour in the New Zealand banking industry. Banks \& Bank Systems, 2(4), 50-65.

Colgate, M. \& Hedge, R. (2001). An Investigation into the Switching Process in Retail Banking Services. The International Journal of Bank Marketing, 19(4), 201-212.

Cooper, D. \& Greenaway, M. (2015). Non-probability survey sampling in official statistics. Available: http://www.ons.gov.uk/ons/guide-method/method-quality/specific/gss-methodology-series/onsworking-paper-series/mwp3-non-probability-survey-sampling-in-official-statistics.pdf. (Accessed: 1 September 2016).

Dawes, J. (2004). Price Changes and Defection Level in a Subscription-Type Market: Can an Estimation Model Really Predict Defection Level? The Journal of Service Marketing, 18(1), 317-325.

Gouws, N. (2012). Identifying factors that influence customer retention in a South African retail bank. Master of Business Administration, North West University, Potchefstroom.

Keaveney, S. M. (1995). Customer switching behavior in service industries: An exploratory study. Journal of Marketing, 59 (2), 71-83.

Khan, N. U. R., Ghouri, A. M., Siddqui, U. A. \& Alam, I. (2010). Determinants analysis of customer switching behaviour in private banking sector of Pakistan. Interdisciplinary Journal of Contemporary Research in Business, 2(7), 96-110.

Kura, K. M., Mat, N. K. N., Gorondutse, A. H., Magaji, A. M. \& Yusuf, A. (2012). Modelling the antecedents of customer switching behaviour in Nigerian banking industry. American Journal of Economics, 6, 29-36.

Manrai, L. A. \& Manrai, A. K. (2007). A field study of customers' switching behaviour for bank services. Journal of Retailing and Customer Services, 14, 208-215.

Masocha, R., Chiliya, N. \& Zindiye, S. (2011). E-banking adoption by consumers in the rural milieus of South Africa: A case of Alice, Eastern Cape, South Africa. African Journal of Business Management, 5(5), 1857-1863.

Mathers, N., Fox, N. \& Hunn, A. (2009). Surveys and questionnaires. National Institute for Health Research (RDS). Available: http://www.rds-yh.nihr.ac.uk/wpcontent/uploads/2013/05/12_Surveys_and_Questionnaires_Revision_2009.pdf. (Accessed: 15 May 2015).

Mugera, W. (2013). Non-probability sampling techniques. Research Methods. Available: https://learning.uonbi.ac.ke/courses/LDP603/work/assig_2/Nonprobability_sampling_ techniques_assignment_1.pdf. (Accessed 9 April 2015).

Onditi, A. A. (2013). Relationship between customer personality, service features and customer loyalty in the banking sector: A survey of banks in Homabay County, Kenya.

Pirzada, S. S., Nawaz, M., Javed, M. U. \& Asab, M. Z. (2014). Which factors influence the customer switching behaviour? (Evidence from the customers of banking sector of Pakistan). European Journal of Business \& Management, 6(11), 134-142.

PricewaterhouseCoopers. (2013). Shaping the bank of the future. South Africa banking survey 2013. Available: www.pwc.co.za/en/assets/south-african-banking-survey-2013.pdf. (Accessed: 19 November 2015).

Redelinghuis, A. \& Rensleigh, C. (2010). Customer perceptions on internet banking information protection. South African Journal of Information Management, 12(1), 1-6.

Subramaniam, R. \& Ramachandram, J. (2012). Customers' switching behaviour in banking industry Empirical evidence from Malaysia. International Journal of Business, Economics \& Law, 1, 156-162.

$\mathrm{Wu}, \mathrm{J}$. (2005). Factors that influence the adoption of internet banking by South Africans in the Ethekweni Metropolitan region. Master of Technology in Marketing. Durban University of Technology, Durban.

Zhang, D., Clemes, M. D. \& Gan, C. (2010). Customer Switching Behavior in the Chinese Retail Banking Industry. International Journal of Bank Marketing, 28(7), 519-546. 